Journal of Educational Research in Developing Areas (JEREDA)

Vol. 2. Issue 2, Pp. 141-152, 2021

http://www.jeredajournal.com

E-mail: info@jeredajournal.com

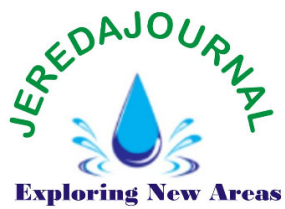

Research Article DOI:https://doi.org/10.47434/JEREDA. eISSN:2735-9107

\title{
CONTRIBUTING FACTORS TO THE PERFORMANCE OF PRE-SERVICE PHYSICAL SCIENCE TEACHERS IN THE LICENSURE EXAMINATION FOR TEACHERS (LET) IN THE PHILIPPINES
}

\author{
Jayson A. Dela Fuente
}

Northern Negros State College of Science and Technology, Philippines

Email: delafuentejayson@nonescost.edu.ph @ittps://orcid.org/0000-0002-8033-0020

Received: $10^{\text {th }}$ June, 2021; Revised: $06^{\text {th }}$ July, 2021; Accepted: $14^{\text {th }}$ August, 2021

\begin{abstract}
Introduction: The Licensure Examination for Teachers (LET) is a measurement of the quality and excellence of the Teacher Education Institutions (TEIs) the country has produced. Passing the licensure exam brings prestige not only to pre-service physical science teachers but also to the academic institution, as it projects the public the impression of producing quality graduates.

Purpose: The objective of the study is to determine the extent of the factors that contribute to the performance of pre-service physical science teachers in the licensure examination for teachers. Moreover, it will serve as a guide for the school administrators of different Teacher Education Institutions (TEIs) in the Philippines on the essential program enhancements and interventions needed to further improve the performance of the pre-service takers in the licensure exam.

Methodology: The purposive sampling technique was used. Since there are only 34 takers on the Licensure Examination for Teachers (LET) in the year 2012, the author decided to utilize the total enumeration with 6 out of the total population being maximized in the reliability testing. A descriptive method of research design was employed to determine the extent of the contributing factors.

Results: The subsequent results revealed that, in terms of teacher and review class factors, it was rated as high extent. School facilities factor was rated moderately extent and student factor as very high extent. Referring to the significant difference in the extent of the factors on the performance of pre-service physical science teachers in the Licensure Examination for Teachers (LET), it was found that there is no significant difference among the factors.

Recommendations/Classroom Implications: The findings suggest that intensive review classes should be strengthened with a strong focus on the specialization and professional education subject areas as they contribute $40 \%$ each of the total result in the LET. Moreover, the school administrators should provide state-of the-art laboratory facilities to enhance pre-service physical science teachers' pedagogies, scientific, and practical skills in physical science.
\end{abstract}

Keywords: Contributing Factors, Licensure Examination for Teachers (LET), Physical Science, Pre-Service Teachers.

Cite paper as:

Crossref Dela Fuente, J.A. (2021). Contributing factors to the performance of preCited-by service physical science teachers in the Licensure Examination for Teachers (LET) in the Philippines. Journal of Educational Research in Developing Areas, 2(2), 141-152. https://doi.org/10.47434/JEREDA.2.2.2021.141.

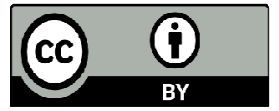

Copyright (c) 2021 The author(s) of this article retain(s) the copyright. 
Journal of Educational Research in Developing Areas (JEREDA)

Vol. 2. Issue 2, Pp. 141-152, 2021

http://www.jeredajournal.com

E-mail: info@jeredajournal.com

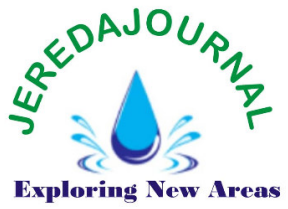

\section{PUBLIC INTEREST STATEMENT}

The study is very vital as it determines the extent of the factors that contribute to the performance of pre-service physical science teachers in the Licensure Examination for Teachers (LET). It will shed light the school administrators of different Teacher Education Institutions (TEIs) in the Philippines given into account the reforms to be proposed to improve the pre-service teachers' performance in the LET.

\section{INTRODUCTION}

Quality education is the foremost and notable goal of every teacher and learning institution. Quality learning becomes indispensable in the hands of uncommitted and ineffective teachers that even a well-structured and the bestdesigned curriculum is doomed to fail. Whilst it is true that some students can learn despite of the teacher, it cannot be denied that the quality of the output of education is a function to the great extent of instruction and students' interaction with their teachers. Bilbao et al, (2006) claimed that the relationship between good teaching and students' achievements elevates the importance of teacher quality in the eyes of parents, educators, and policymakers. Research shows that good teaching does not happen by accident. It requires teachers' dedication, creativity, and innovative attributes to successfully achieve quality teaching and learning in the educational system (Dela Fuente, 2021). While some teachers may have a special gift to help students to learn, good teaching encompasses critical elements such as knowledge of the learning process, child development, teachers experiences, academic ability, and content knowledge. Knowing about these critical elements and having the ability to contextualize them to the learner makes learning a much more meaningful and relevant pursuit, as well as the teacher ideal (Dela Fuente, 2019). Salandanan (2009) exposes that a single factor can contribute to an improve student achievement than the guarantee of a quality teacher in every classroom. No amount of classroom facilities and instructional materials can produce the desired learning outcome without a teacher at the centre of the stage.

Ricote, (2008), believed that teachers' certification is considered to be one of the indicators of quality teachers, hence the need to examine its role in student achievement. This was strengthened by Dela Fuente (2021), who claimed that the level of competence of teachers has been achieved by practicing teachers through the academic performance of students. The success of pre-service teachers in a professional examination means so much to the individual and the institution granting the degree. Reflects the quality of education it provides to its graduates. Thus, to keep pace with the demands of global competitiveness or in the desire to become globally competent in education something must be worked on towards continual improvement that is, adopting a change. It needs continuous effort and time with the participation and collaboration of all stakeholders in the education process (Dela Fuente \& Biñas, 2020).

The Licensure Examination for Teachers (LET) provides a valuable framework against which teaching practice can be measured and certified. The professional license serves as a passport to practice the profession (Salandanan, 2005). It is a very important examination as one's teaching career may well depend on its outcome, this is a source of worry for teachers. Passing the licensure examination means that a professional teacher will have the rights and privileges as a licensed teacher given by the Professional Regulation Commission (PRC) in accordance with the Magna Carta for teachers. He or she will therefore qualify to teach in government recognized schools in the country. Passing the LET brings prestige not only to the passers or to their families but also to the school where they study. And understanding why pre-service fail is an excellent way of recognizing and avoiding the most common pitfalls and traps. There is no magic in passing; solid training, broad 
Journal of Educational Research in Developing Areas (JEREDA)

Vol. 2. Issue 2, Pp. 141-152, 2021

http://www.jeredajournal.com

E-mail: info@jeredajournal.com

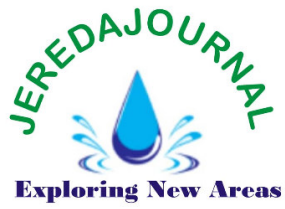

experience, and clear thinking are all basic requirements, however, it was believed that a person's educational accomplishment cannot be predicted by just finishing the course alone. The extent of knowledge acquired is also measured by his performance on a given examination. She further said that if a person has excelled academically in the past, there is a greater chance for him or her to have a successful performance in an examination. The Republic Act 7836, also known as the Philippine Professionalization Act of 1994, recognized the vital role of teachers in nation-building and development through responsible and literate citizenry. As such, the state shall ensure and promote quality education by proper supervision and regulation of the licensure examination and professionalization of the practice of the teaching profession.

In the context of quality education, it has been imperative to improve the quality of teaching in the Philippines to bring about changes that in turn speeded up the pace of events and added more color to the quality of human living. In the field of education, however, this global shift has been scarcely perceptible especially to the typical student goals because changes in quality education have not been as fast and dramatic as in other fields. This being the case, the school has to struggle to strengthen the programs to promote the demands of the outside world. As a result, demands to examine the teaching capabilities of each qualified teacher is a must today to increase and improve the percentage of passers in every Teacher Education Institution in the country. To create a new vision of the learning institution and to have a technological development of its facilities that could lead to the major changes in the way that teachers teach and the students learn effectively.

The Northern Negros State College of Science and Technology (NONESCOST), as an institution of learning and knowledge provider is expected to produce quality teacher education graduates who are competent and globally competitive in the teaching

profession. However, the NONESCOST teacher education department faced difficulty in providing more licensed teachers. These were supported by data from the Professional Regulation Commission (PRC) result on the teacher's board examination since 2010-2012. The data revealed that in the year 2010 out of 63 takers only 6 passed with $9.52 \%$ as the overall performance and $25.86 \%$ the national passing rate. By the year 2011, there are only 13 passers out of 70 takers with an overall performance of $18.57 \%$ with a $13.45 \%$ national passing rate. And in the year 2012, out of 79 takers, only 23 passed with $29.11 \%$ as the overall performance and $43.50 \%$ national passing rate. Given this overview, the author takes interest to conduct an investigative study to gather empirical evidence with regards to the factors that contribute to the performance of pre-service physical science teachers in the licensure examination for teachers, Licensure Examination for Teachers (LET) with the end view to increase the number of passers and elevate the national passing rate performance of the Teacher Education Department of the Northern Negros State College of Science and Technology (NONESCOST) Licensure Examination for Teachers (LET).

The Input-Process-Output (IPO) system serves as the backbone and flow of the study. The contributing factors to the performance of the pre-service physical science teachers in the Licensure Examination for Teachers (LET) in the three subject areas the Specialization, Professional, and General are the variables to be analyzed using a validated survey questionnaire to determine the extent of the identified contributing factors. The findings will shed light on what appropriate intervention should then be provided.

\section{STATEMENT OF PROBLEM}

The Licensure Examination for Teachers (LET) given by the Professional Regulation Commission (PRC) is a measurement of the quality and excellent teachers and educators that the Teacher Education Institutions (TEIs) of the 
Journal of Educational Research in Developing Areas (JEREDA)

Vol. 2. Issue 2, Pp. 141-152, 2021

http://www.jeredajournal.com

E-mail: info@jeredajournal.com

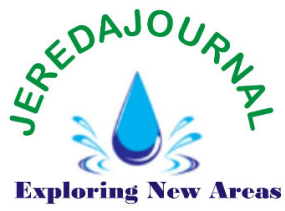

country have been producing throughout the years. Passing the licensure exam brings prestige not only to the preservice teachers but also to the academic institution as it projects to the public the impression of producing quality graduates. However, just like any other TEIs in the country, Northern Negros State College of Science and Technology (NONESCOST) has experienced the difficulty of having a higher passing rate in the LET. It is on this premise that prompts the author to conduct an investigative study to determine the extent of the identified contributing factors to pre-service physical science teachers with the end view to elevate the performance of NONESCOST in the given licensure exam.

\section{PURPOSE OF THE STUDY}

1. To determine the extent of the contributing factors to the performance of pre-service physical science teachers in the Licensure Examination for Teachers (LET) of the Teacher Education Department of Northern Negros State College of Science and Technology (NONESCOST) Philippines. Specifically, the study seeks to answer the following questions.

\section{RESEARCH QUESTIONS}

1. What are the extents of the teacher factor to the performance of pre-service physical science teachers in the Licensure Examination for Teachers?

2. What are the extents of School Facilities to the performance of pre-service physical science teachers in the Licensure Examination for Teachers (LET)?

3. What are the extents of Review Class of pre-service physical science teachers in the Licensure Examination for Teachers (LET)?

4. What are the extents of Student factor to the performance of preservice physical science teachers in the Licensure Examination for Teachers (LET)?

\section{HYPOTHESIS}

1. There is no significant difference on the extents of the contributing factors to the performance of the pre-service physical science teachers in the Licensure Examination for Teachers (LET)on the following subject areas Specialization, Professional, and General?

\section{METHODOLOGY \\ Research Design}

The author utilized a descriptive survey research design. Descriptive research according to Best and Kahn (2006) describes and interprets what it is. It is concerned with conditions or relationships that exist, practices that prevail, beliefs and processes that are going on, effects that are being felt, or trends that are developing. Hence, the method used is deemed appropriate as it determines the extent of contributing factors to the performance of pre-service physical science teachers in the licensure examination for teachers.

\section{Population and Sample}

The participants of the study are the graduates of Bachelor of Secondary Education major in Physical Science of the Teacher Education Department of the Northern Negros State College of Science and Technology (NONESCOST) Philippines batch 2012 who took the Licensure Examination for Teachers (LET). The author used the purposive sampling technique. Since there are only 34 takers on the Licensure Examination for Teachers (LET)in the year 2012 the author decided to utilize the total enumeration with six out of the total population was maximized in the reliability testing.

\section{Instruments for Data Collection}

To determine the extent of contributing factors to the performance of the pre-service physical science teachers in the Licensure Examination for Teachers (LET)the author does thorough surfing and researching in the internetrelated literature of items that can suit the objectives of the study. Out of the related items researched, the author 
Journal of Educational Research in Developing Areas (JEREDA)

Vol. 2. Issue 2, Pp. 141-152, 2021

http://www.jeredajournal.com

E-mail: info@jeredajournal.com

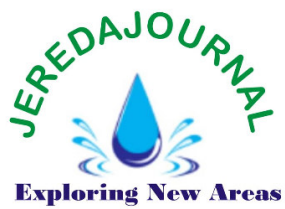

modified and developed a self-made closed-ended survey questionnaire with four sections that correspond to the contributing factors; Section 1: Teacher, Section 2: School Facilities, Section 3: Review Class, and Section 4: Student (see Appendix A). A closed-ended questionnaire according to Calderon and Gonzales 1994, is regarded as a guided response type, closed form, or restricted where the responses are guided in answering questions by providing options like in multiples choice test while answers are based on the response of the respondents to the survey questionnaire which employ ordinal rating scale. The instrument used was subjected for validation by a panel of experts to evaluate each of the items in the test, whether or not items reflect what it intends to measure. Validity refers to the core of any form of assessment that is trustworthy and accurate (Bond, 20030). The author subjected the instrument to expert validation using the criteria developed by Good and Scates (1972). The author's-made questionnaire was presented to the three validators who are considered experts in the field. They examined the research instrument item by item and rated the suitability and appropriateness of the questions. They examined the research instrument item by item and rated the suitability and appropriateness of the questions. Recommendations and suggestions for improvement were taken into account and were given due importance by the author. Reliability as defined by Shuttleworth (2015) is the degree of consistency and precession a measuring instrument demonstrates. In this study, the reliability of the test was determined using the test-retest method. In this study, the reliability of the test was determined using the test-retest method. Using this reliability technique, a dry run of the questionnaire was conducted to a group of six selected respondents among the total respondents. The results of the two administrations were correlated using the Pearson Product Moment of Correlation Significance to determine the extent consistency of the respondents' answer. In the conduct of the reliability

of the research instrument, it revealed that out of six respondents, all of them were consistent in their responses.

\section{Procedure of Data Analysis}

The author sent a letter to the college registrar asking permission to conduct the study and to access the list of graduates in Bachelor of Secondary Education major in Physical Science of the Teacher Education Department of the Northern Negros State College of Science and Technology (NONESCOST) Philippines batch 2012 with their complete name, address, and contact number. The author then sends text messages to the concerned asking permission to be the respondents of the study. The respondents were then given informed consent and explained to them the purpose of their participation and assured that their responses will be treated with the utmost confidentiality. To ensure one-hundred percent of data retrieval, the authors personally administered the survey questionnaire to the respondents, but there are instruments that was mailed to those respondents who are living and working away from the author's place.

\section{Methods of Data Analysis}

The data were analyzed using the appropriate statistical tools in the Statistical Package Social Sciences (SPSS) software. To provide precise analysis and interpretation in analyzing the data, the following statistical tools were utilized. To determine the extent of the contributing factors to the performance of pre-service physical science teachers in the Licensure Examination for Teachers (LET)mean were used. To determine the extent of the significant difference on the extent of the contributing factors on the different subject areas, the Specialization, Professional and General, the Analysis of Variance or ANOVA was employed.

\section{RESULTS}

Research Question 1: What are the extents of Teacher factor to the performance of pre-service physical science teachers in the Licensure Examination for Teachers (LET)? 
Journal of Educational Research in Developing Areas (JEREDA)

Vol. 2. Issue 2, Pp. 141-152, 2021

http://www.jeredajournal.com

E-mail: info@jeredajournal.com

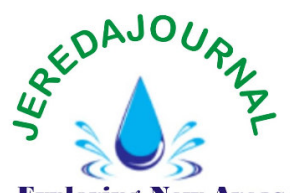

Exploring New Areas

Table 1. Extent of Teacher Factor

\begin{tabular}{lllll}
\hline Factor & Subject Areas & Mean & Sd & $\begin{array}{l}\text { Verbal } \\
\text { Interpretation }\end{array}$ \\
\hline & Specialization & 3.74 & .70918 & High Extent \\
Teacher & Professional & 3.93 & .73747 & High Extent \\
& General & 3.77 & .45225 & High Extent \\
\hline
\end{tabular}

In reference to table 1 , the mean score as to the teacher factor in three subject areas; the specialization, professional, and general it gained a mean score of $3.74,3.93$, and 3.77 respectively which are interpreted as high extent. Teachers as at the forefront in the success of the academic institution on producing quality graduates have a vital role to play in sharpening the minds and preparing students for any diagnostic test or examination.

Research Question 2: What are the extents of School Facilities to the performance of pre-service physical science teachers in the Licensure Examination for Teachers (LET)?

Table 2. Extent of School Facilities Factor

\begin{tabular}{lllll}
\hline Factor & Subject Areas & Mean & Sd & Verbal Interpretation \\
\hline & Specialization & 3.34 & .94697 & Moderate Extent \\
School & Professional & 3.23 & .91073 & Moderate Extent \\
Facilities & General & 3.38 & .98503 & Moderate Extent \\
& & & & \\
\hline
\end{tabular}

Table 2 revealed that the mean score as to the school facilities factor in three subject areas; the specialization, professional, and general it projected a mean score of $3.34,3.23$, and 3.38 respectively which are interpreted as moderate extent.
Research Question 3:What are the extents of Review Class of pre-service physical science teachers in the Licensure Examination for Teachers (LET)?

Table 3. Extent of Review Classes Factor

\begin{tabular}{lllll}
\hline Factor & Subject Areas & Mean & Sd & Verbal Interpretation \\
\hline & Specialization & 0.00 & 0.00 & No Review Conducted \\
Review & Professional & 3.68 & .58387 & High Extent \\
Class & General & 3.74 & .60941 & High Extent
\end{tabular}

As reflected in table 3 , the mean score as to the review class factor revealed that the professional and general subjects have a mean score of 3.68 , and 3.74 respectively which are interpreted as high extent. However, the takers have disclosed that there are no review classes conducted on the major subjects. Furthermore, they revealed that the review centre was not able to provide 
Journal of Educational Research in Developing Areas (JEREDA)

Vol. 2. Issue 2, Pp. 141-152, 2021

http://www.jeredajournal.com

E-mail: info@jeredajournal.com

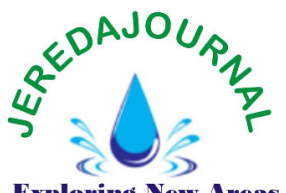

experts and review materials for specialization subjects.

performance of pre-service physical science teachers in the Licensure Examination for Teachers (LET)?

Research Question 4: What are the extents of Student factor to the

Table 4. Extent of Student Factor

\begin{tabular}{lllll}
\hline Factor & Subject Areas & Mean & Sd & Verbal Interpretation \\
\hline \multirow{4}{*}{ Student } & Specialization & 4.01 & .47328 & High Extent \\
& Professional & 4.16 & .37830 & High Extent \\
& General & 4.24 & .47433 & Very High Extent \\
\hline
\end{tabular}

Results show in table 4, that the mean score as to the student factor in three subject areas; the specialization and professional garnered a mean score of 4.01 and 4.16 respectively which are interpreted as high extent. On the other hand, in the general subject it has a mean score of 4.24 which is interpreted as a very high extent.
Hypothesis 1: There is no significant difference on the extents of the contributing factors to the performance of pre-service physical science teachers in the Licensure Examination for Teachers (LET)on the following subject areas Specialization, Professional, and General.

Table 5. Extent of the Contributing Factors to the Performance of Pre-Service Physical Science Teachers in the Licensure Examination for Teachers (LET) in three subject areas (Specialization, Professional, General)

\begin{tabular}{|c|c|c|c|c|c|c|}
\hline $\begin{array}{l}\text { Source of } \\
\text { Variance }\end{array}$ & df & $\begin{array}{l}\text { Sum o } \\
\text { Sq. }\end{array}$ & $\begin{array}{ll}\text { Mean } \\
\text { Sq. }\end{array}$ & $\begin{array}{l}\text { Comp. } \\
\text { F }\end{array}$ & $\begin{array}{l}\text { Sig. } \\
\text { Val. }\end{array}$ & $\begin{array}{l}\text { Verbal } \\
\text { Interpretation }\end{array}$ \\
\hline $\begin{array}{l}\text { Teacher } \\
\text { Factor }\end{array}$ & 2 & .611 & .306 & .666 & .517 & $\begin{array}{l}\text { No Significant } \\
\text { Difference }\end{array}$ \\
\hline $\begin{array}{l}\text { School } \\
\text { Facilities } \\
\text { Factor }\end{array}$ & 2 & .081 & .041 & .046 & .955 & $\begin{array}{l}\text { No Significant } \\
\text { Difference }\end{array}$ \\
\hline $\begin{array}{l}\text { Review } \\
\text { Classes } \\
\text { Factor }\end{array}$ & 1 & .046 & .046 & .122 & .728 & $\begin{array}{l}\text { No Significant } \\
\text { Difference }\end{array}$ \\
\hline $\begin{array}{l}\text { Student } \\
\text { Factor }\end{array}$ & 2 & .825 & .412 & 1.940 & .150 & $\begin{array}{l}\text { No Significant } \\
\text { Difference }\end{array}$ \\
\hline
\end{tabular}

As reflected in table 5 it generates a difference (df) of 2 for the statistical idea that there are no review classes conducted for specialization subject area, thus its extent is not perceivable as there is no input under this consideration. Furthermore, Table 5 highlights that Volume 2, Number 2 there is no significant difference in the extent of the factors that contribute to the performance of physical science teachers before service in the Licensure Examination for Teachers (LET) in the different subject areas in specialization, professional, and general. 
Journal of Educational Research in Developing Areas (JEREDA)

Vol. 2. Issue 2, Pp. 141-152, 2021

http://www.jeredajournal.com

E-mail: info@jeredajournal.com

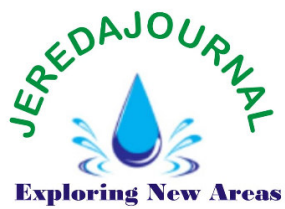

\section{DISCUSSIONS}

Consequently, Visco (2020) considered teachers as one of the contributing factors to the performance of pre-service teachers in a given competitive examination. Teachers who are fully equipped with teaching pedagogies, technical skills, and competence help improve and deliver quality education. Works of literatures have pointed out that teachers are a predictor in the success of pre-service physical science teachers in the Licensure Examination for Teachers (LET), as such, they should possess attributes that are essential to produce quality graduates in the education industry. The current result affirmed the study of Quiambao et al. (2015) who pointed out that teachers have a significant contribution to the academic success of students and in the LET for pre-service service. Academic institutions are expected to provide state-of-the-art facilities to increase the interest of students in learning and performing meaningful learning activities with the available facilities.

Rabanal (2016) emphasized that to achieve good performance in the LET facilitates should be readily available and accessible to students and pre-service physical science teachers so that they can develop their manipulative skills through hands-on activities with the aid of the different learning facilities. Ferrer et.al. (2015) emphasized that review classes must be provided to condition the mind of the pre-service physical science teachers by preparing mock examinations based on the paradigm and structure of the Professional Regulation Commission (PRC) in the LET examination. The inference drawn based on the figures revealed that the pre-service physical science teachers got a very good academic standing in the general subject, which indicates further that general subjects are essential in the success in the LET. This was strengthened by Mushtaq et al. (2012) that all subject areas are essential in the success of any competitive examinations. Therefore, they should be taken into account equal consideration by providing the appropriate pedagogies which can capacitate the knowledge of the preservice physical science teachers when they take the licensure examination.

$\mathrm{Li}$ (2012) stressed that effort could only be regarded as an indirect factor but not a necessary factor in bridging the success in the given examination. This was affirmed by Weimer (2014) who established that physical science teachers in pre-service should participate more in different learning activities to improve their pedagogical knowledge in preparation for any examination. The pre-service physical science teachers tend to take the examination without a full understanding of the significant contribution of body and mind preparation (Al-Amari \& Al-Khamees, 2015). Regarding the student factor, Svartdal et al. (2018) and Antiojo (2017) posited that better understanding the nature of pre-service teacher preparation before taking the examination is an important element for a successful result. This was supported by Rudio (2016) that academic success and preparation have a significant relationship with the good performance of LET takers. Therefore, Foronda (2017) suggested that the college entrance score be a prerequisite for admission to the college of education/department and that their average grade is used for the retention policy.

\section{CONCLUSION}

The Licensure Examination for Teachers (LET) is a measurement of quality and excellence that the Teacher Education Institutions (TEIs) the country produced. Passing the licensure exam brings prestige not only to the preservice physical science teachers but also to the academic institution as it projects the public the impression of producing quality graduates. In the Philippines, once pre-service physical science teachers pass the LET they are entitled to be called Licensed Professional Teacher (LPT) and were given all the rights and privileges by law inscribed in the Magna Carta for Public School Teachers upon taking the oath of allegiance to the teaching profession a license to teach to any academic learning institution. TEIs in 
Journal of Educational Research in Developing Areas (JEREDA)

Vol. 2. Issue 2, Pp. 141-152, 2021

http://www.jeredajournal.com

E-mail: info@jeredajournal.com

the country are persistently looking for approaches to improve the LET performance to meet the demands of the industry globally. On this given perspective, the author conducted an investigative study to determine the extent of contributing factors to the performance of pre-service physical science teachers in the Licensure Examination for Teachers (LET)with anticipations that the findings will shed light in providing essential inputs to enrich TEIs curriculum to strengthen the delivery of pedagogical and technical skills for pre-service physical science teachers to hurdle successfully the LET.

Based on the findings, the following conclusions were drawn. The teacher and the review classes factors are too high extent. However, it was noted that no specialization review classes were provided, as revealed by the participants during the survey questionnaire, which was inferred to contribute to the success of the Licensure Examination for Teachers (LET).

Moreover, it conveys that the takers believed that school facilities are not directly an external factor for LET performance, whilst the student factor gained a very high extent which means the takers of LET considered the student factor as a major contributory element for a successful LET result. Furthermore, the extent of the contributing factors to the performance of the pre-service physical science teachers in the Licensure Examination for Teachers (LET)in one selected State College in Northern Negros Philippines was not significant.

\section{RECOMMENDATIONS}

Teachers Education Institutions (TEIs) can consider the following recommendations to strengthen the performance of physical science teachers before service on the Licensure Examination for Teachers (LET) and to have excellent and quality teachers in the country:

1. The TEIs may provide intensive review classes in the three subject areas which are specialization, professional, and general.

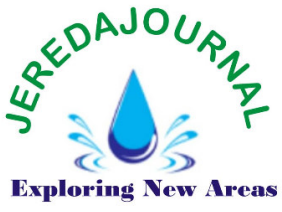

2. The TEIs may provide ample time to focus more on the review of the specialization and professional education subject areas in which it contributes $40 \%$ respectively to the result of the LET takers.

3. The TEIs may consider the idea of having the admission and retention policy based on academic performance to ensure having quality pre-service teachers.

4. School administrators must provide state-of-the-art laboratory facilities congruent to the specialization offered, Physical Science, to improve the pedagogical, scientific, and technical skills of pre-service physical science teachers.

Conflicts of Interest: The author declares no conflict of interest.

\section{Disclaimer Statement}

I hereby declare that this paper is my original research work. All text either quoted directly or paraphrase have been properly cited. Full bibliographic details are given in the reference list.

\section{Notes on Author}

Jayson A. Dela Fuente is a faculty in Northern Negros State College of Science and Technology in the Philippines. He is pursuing a $\mathrm{PhD}$ in instructional leadership education specializing in general science. $\mathrm{He}$ holds degrees of MA in Education, specializing in general science with cum laude honors, and BS in Education, specializing in physical science. Currently, he is teaching physics, forensic chemistry, earth and environmental science, and professional education subjects to college students. His research interests include science education, inclusive and special education, instructional leadership education, pedagogy and teacher education, and technology education. He is an advocate of inclusive education in academia and was awarded as the Philippines "Happiest Person With Disability 2019" by CebuanaLhullier Incorporated. 
Journal of Educational Research in Developing Areas (JEREDA)

Vol. 2. Issue 2, Pp. 141-152, 2021

http://www.jeredajournal.com

E-mail: info@jeredajournal.com

\section{REFERENCES}

Al-Amari, H.G.,\& Al-Khamees, N. (2015). The Perception of College Students about a Healthy Lifestyle and its Effect on their Health. Journal of Nutrition \& Food Sciences.https://www.omicsonline .org/open-access/the-perceptionof-college-students-about-ahealthy-lifestyle-and-its-effect-ontheir-health-215596001000437. php?aid $=63506$.

Antiojo. L. (2017). Performance of education graduates in the Licensure Examination for Teachers (LET). International Journal of Social Sciences, 3(2), 1363-1384.

Best, J.W. \& Kahn, J.V. (2006).Research in Education. pdf. https://www.academia.edu/53825 94/Research_in_Education_Tenth Edition

Bilbao, P.P., Corpuz, Llagas,A.T. \&Salandanan, G.G. (2006). The teaching profession. Lorimar Publishing Company, Inc. Books..

Bond, T. (2003). Validity and assessment: A Rasch measurement perspective.Metodoliga de lasCienciasdelComportamento, 5(2), 179-194.

Campbell, D. \& Stanley, J. (1963). Experimental and quasiexperimental designs for research. Rand-McNally.

Quiambao, D.T., Baking, E.G., Buenviaje, L.B., Nuqui, A.V. \& Cruz, R.C. (2015). Predictors of Board Exam Performance of the DHVTSU College of Education Graduates.

Dela Fuente, J.A. \& Biñas, L.C. (2020). Teachers' competence in information and communications technology (ICT) as an educational tool in teaching: An empirical analysis for program intervention. Journal of Research in Education, Science and Technology, 5(2), 61-76.

Dela Fuente, J.A. (2019). Driving Forces of Students' Choice in specializing science: a science education context in the Philippines
Perspective. The Normal Lights, 13(2), 225-250.

Dela Fuente, J.A. (2021). Facebook messenger as an educational platform to scaffold deaf students' conceptual understanding in environmental science subject: A single group quasi-experimental study. International Journal of Education, 14(1), 19-29. doi:10.17509/ije.v14i1.31386.

Dela Fuente, J.A. (2021). Implementing inclusive education in the Philippines. College teacher experiences with deaf students. Issues in Educational Research, 31(1), 94-110. http://www.iier.org.au/iier31/dela -fuente.pdf

Ferrer, R.C., Buted, D.R. \& Irma, M.C. (2015). Performance of BSEdscience graduates in licensure examination for teachers: Basis for a regression. model. Asia Pacific Journal of Multidisciplinary Research, 3(5), 1-6.

Foronda, M.S. (2017). Predictors of Licensure Examination for Teachers (LET)(LET) performance: A mediation analysis. Association for Computing Machinery.

Good, C.V. \&Scates, D.E. (1972). In Paler-Calmorin, L., \&Calmorin, M.A. (1997). Statistics in education and the sciences. Statistics in education and the sciences. Manila, Philippines: Rex Bookstore.

Li, L.K.Y. (2012). A study of the attitude, self-efficacy, effort and academic achievement of city $u$ students towards research methods and statistics. discovery-ss student.EJournal, 1(2), 154-183. http://ssweb.cityu.edu.hk/downlo ad/RS/E-Journal/journal8.pdf

Mushtaq, I., Nawaz, S., Mohammad, K., Jinnah, A. \& Khan, S. (2012). Factors affecting students' academic performance, type double blind peer review. International Research Journal, Publication of Global Journals Inc., 12(9), 121-215. 
Journal of Educational Research in Developing Areas (JEREDA)

Vol. 2. Issue 2, Pp. 141-152, 2021

http: / / www.jeredajournal.com

E-mail: info@jeredajournal.com

Quiambao, D.T., Baking, E.G., Buenviaje, L.B., Nuqui, A.V. \& Cruz, R.C. (2015). predictors of board exam performance of the dhvtsu college of education graduates. Journal of Business \& Management Studies1(1), 1-4.

Rabanal, G. (2016). Academic achievement and let performance of the bachelor of elementary education graduates, University of Northern Philippines. International Journal of Scientific and Research Publications, 6(6), 455-461.

Republic Act 7836: Philippine Teachers Professionalization Act of 1994. An Act to Strengthen the Regulation and Supervision of the Practice of Teaching in the Philippines and Prescribing a Licensure Examination for Teachers (LET)and for other Purposes. https://pcw.gov.ph/republic-act7836-philippine-teachersprofessionalization-act-of-1994/

Republic Act No. 4670 June 18, 1966. The Magna Carta for Public School Teachers.

https://www.lawphil.net/statutes/ repacts/ra1966/ra 4670 1966.ht $\underline{\mathrm{ml}}$

Ricote, E.E. (2008). Philippine public administration as a field of study: Enduring and emerging areas, challenges and prospects. Philippine Journal of Public Administration, 52(2-4), 167-194.

Rudio, V.O. (2016). Performance of teacher education graduates, DMMMSU-NLUC, Philippines in the Licensure Examination CY 2011 to 2013. International Journal of Critical Reviews, 6(3), 1-

Salandanan, G.G.(2009). Teacher education. QC, KATHA Publishing Co., Inc.

Salandanan, G.G. (2005). Teaching and the teacher. Adriana Printing Co., Inc.

Shuttleworth, M. (2015). Internal consistency reliability.https://explorable.com/i nternal-consistency-reliability

Svartdal, F., Granmo, S. \&Faerevaag, F.S. (2018). On the behavioral side of procrastination: Exploring behavioral delay in real-life settings. Frontiers in Psychologyl, 9:746.

DOI:10.3389/fpsyg.2018.00746.

Visco, D.A. (2020). Predictors of performance in the licensure examination for teachers. Asian Journal of Multidisciplinary Studies, 3(1), 35-40.

Weimer, M. (2014). Students and attention: An interesting analysis. https://www. facultyfocus. com/articles/teaching-andlearning/students-attentioninteresting-analysis/

To the Respondents:

This questionnaire is designed to determine the extent of the contributing factors to the performance of pre-service physical science teachers in the Licensure Examination for Teachers (LET) in the Philippines. Please check the space provided that corresponds to your response. Rest assured that your responses will be treated with the utmost confidentiality. The researchers will appreciate your cooperation and participation.

PART 1: Profile of the Respondents

Name (optional)

Sex

Birthdate

PRC Application Number

Permanent Address

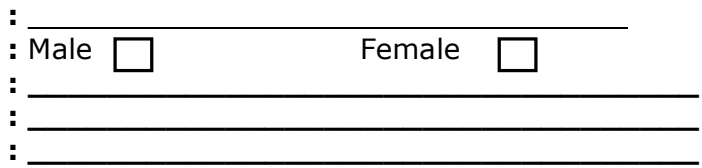

PART II: Contributing Factors to the Performance of Pre-Service Physical Science Teachers in the Licensure Examination for Teachers (LET) in the Philippines 
Journal of Educational Research in Developing Areas (JEREDA)

Vol. 2. Issue 2, Pp. 141-152, 2021

http://www.jeredajournal.com

E-mail: info@jeredajournal.com

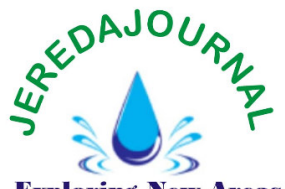

Direction: Read each statement below and using the scale check the appropriate box that corresponds to your rating.

Numerical Rating

5
4
3
2
1

Mean Score Range

$5.00-4.50$

$4.49-3.50$

$3.49-2.50$

$2.49-1.50$

$1.49-1.00$

\section{Descriptive Interpretation}

Very High Extent

High Extent

Moderate Extent

Low Extent

Very Low Extent

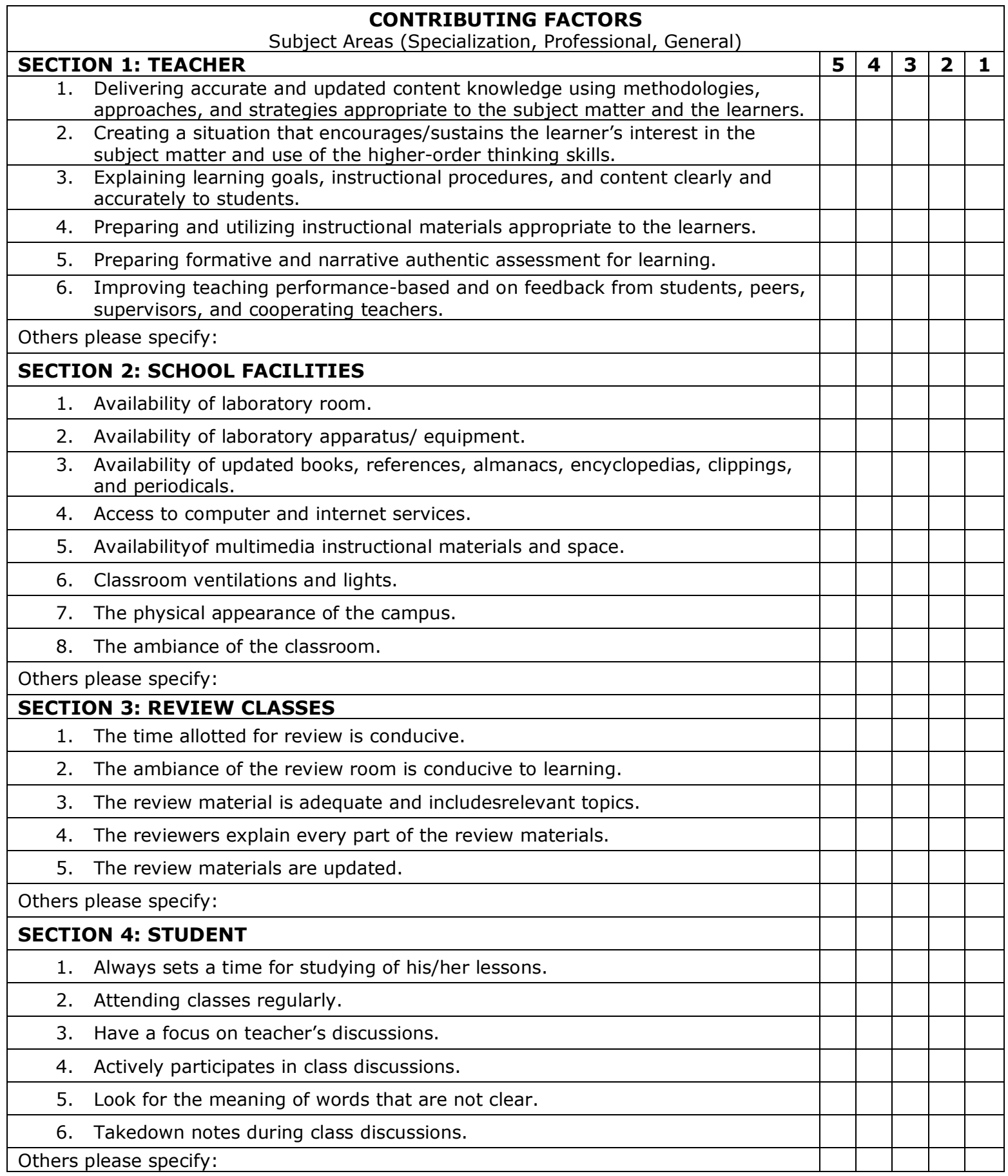

